\title{
Effects of Cobalt Chloride on the Metabolism of Free Fatty Acids in Isolated Liver Cells from Rabbits and Rats
}

\author{
Hiroyuki Morita and Yukikazu Kuno \\ Department of Hygiene, School of Medicine, Showa University, Tokyo
}

\section{INTRODUCTION}

Recent work in our laboratory has shown that cobalt chloride caused a marked increase in the plasma triglyceride of rabbits $^{1 \sim 3)}$, but that the triglyceridemia induced by cobalt in rats ${ }^{45)}$ was not much enhanced. In the postabsorptive state, plasma triglyceride is derived mainly from the liver, so that its concentration depends upon increased synthesis and on release from the live $\mathrm{i}^{\mathrm{v})}$.

The elevation of plasma triglyceride induced by cobalt chloride may be explained by the fact that cobalt affects lipid metabolism in the liver, but little is known about the mechanisms behind such changes. Cobalt ions in vitro inhibit the oxidation of pyruvate and $\alpha$-ketoglutarate by mitochondrial suspensions of rat liver and thigh muscle ${ }^{7,8)}$. If these two metabolic steps are inhibited, then the Krebs citric cycle will not operate, consequently increased ketogenesis will be produced. Ohyama et al. ${ }^{9}$ demonstrated that cobalt could not increase the concentration of plasma ketone bodies to more than the level of starved rabbits. Although cobalt injected into rabbits promoted the plasma triglyceride turnover ${ }^{10)}$, no enhanced incorporation of labelled palmitate into triglyceride has been reported.

Recent studies indicate that isolated cells may be an ideal system to study glycerolipid synthesis ${ }^{11}$ and secretion by the liver ${ }^{12}$. Liver cells from fed rats esterified the major portion of palmitate to triglycerides and phospholipids. An intermediate quantity was oxidized to ketone bodies, and a smaller amount was oxidized to $\mathrm{CO}_{2}$. The partition of added palmitate between the oxidative and esterification pathways was inverted by fasting.

The main objective of the present study was to ascertain whether or not isolated liver cells from starved animals, that had been previously treated with cobalt chloride, differ in their metabolic reactions to palmitic acid, i.e. esterification to triglyceride and phospholipids, oxidation to ketone bodies and $\mathrm{CO}_{2}$, from non treated cells.

Our second objective was to investigate, using isolated rabbit and rat liver cell preparations, whether the higher plasma triglyceride concentration found in cobalt-treated rabbits is due to increased synthesis and to secretion of triglyceride from the liver.

We also studied the effect of cobalt ions on the metabolism of lipids in isolated liver cells incubated with or without cobalt.

\section{MATERIALS AND MethodS}

\section{ANIMALS}

Adult male rabbits weighing 3 to $4 \mathrm{~kg}$, and male Wister strain rats weighing 300 to $400 \mathrm{~g}$ were used. These were each divided into three groups. In the cobalt-treated group of animals, cobalt chloride (10\% in saline solution) at a dose of $25 \mathrm{mg} / \mathrm{kg}$ was injected sub- 
cutaneously once a day for three days. The same volume of saline solution was given subcutaneously to the starved group of animals. This group and the cobalt-treated group were starved for 3 days beginning after the first injection. The third group, designated as the normal fed group, was allowed unrestricted access to rabbit or rat chow (Oriental Co.).

\section{PREPARATION OF HEPATOCYTES}

Parenchymal liver cells were isolated by a modification of the enzymatic procedure described by Berry and Friend ${ }^{13)}$. After collection of the blood samples, rabbits were anesthetized with a slow injection of sodium pentobarbital into an ear vein; rats were anesthetized with ether. After exposure of the peritoneal cavity by incision, the portal vein was canulated then perfused with $450 \mathrm{ml}$ of warm $\left(37^{\circ} \mathrm{C}\right) 15 \mathrm{mM}$ HepesHanks solution ( $\mathrm{pH} \mathrm{7.4)}$ ) at a rate of $130 \mathrm{ml} / \mathrm{min}$ in the rabbit, and $70 \mathrm{ml} / \mathrm{min}$ in the rat. After this initial perfusion, the liver was perfused with the enzyme solution for $30 \mathrm{~min}$ at

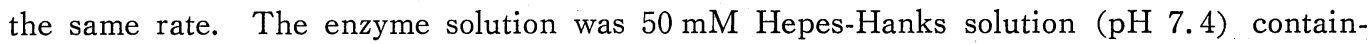
ing $0.5 \%$ bovine serum albumin, in which $0.05 \%$ collagenase was dissolved. The liver was then removed and placed in a beaker containing $0.5 \%$ bovine serum albumin in $50 \mathrm{mM}$ Hepes-Hanks solution, $\mathrm{pH} 7.4$, then it was finely minced with scissors and broken up with a plastic fork. The suspension was filtered through four layers of nylon mesh, and cells were separated from the debris by centrifugation at $100 \times \mathrm{g}$ for $30 \mathrm{sec}$.

The precipitated cells were resuspended in $50 \mathrm{mM}$ Hepes-Hanks solution containing $0.5 \%$ bovine serum albumin, $\mathrm{pH} 7.4$, then centrifuged again. The supernatant was decanted and the precipitates were weighed. The cells were then dissolved in $50 \mathrm{mM}$ Hepes-Hanks solution, containing $0.5 \%$ bovine serum albumin, to make a $10 \%$ suspension. The 10\% suspension was filtered again through nylon mesh before use.

The viability of the cell preparations was checked by the exclusion of trypan blue. Preparations used in these experiments contained more than $90 \%$ viable cells.

\section{PREPARATION OF SUBSTRATES}

$\left[1-{ }^{14} \mathrm{C}\right]$ palmitic acid $(59 \mathrm{mCi} / \mathrm{mmol})$ was purchased from the Radiochemical Centre Amersham, England. $30 \mu \mathrm{Ci}\left[1-{ }^{14} \mathrm{C}\right]$ palmitic acid in benzene solution was dried under nitrogen at $30-40^{\circ} \mathrm{C}$. The dried, labelled palmitic acid was added to $115.4 \mathrm{mg}$ of unlabelled palmitic acid and dissolved in ethanol. The ethanol solution was saponified with alcoholic $\mathrm{KOH}\left(70-80^{\circ} \mathrm{C}\right)$. After the color of the solution had been changed with phenol-red, it was dried at $100^{\circ} \mathrm{C}$ throughly under nitrogen. The dried, saponified material was dissolved in $18 \mathrm{~m} l$ of redistilled water. Eighteen milliliters of the solution was added to $90 \mathrm{~m} l$ of the albumin solution, containing $6 \mathrm{~g}$ of fatty acid free albumin dissolved in $6 \mathrm{~m} l$ of $1 \mathrm{M}$ Hepesbuffer, pH 7.5.

The solution was brought to a final volume of $120 \mathrm{~m} l$ with $12 \mathrm{~m} l$ of a ten fold concentration of calcium-free and glucose-free Hanks solution.

\section{INCUBATIONS}

One milliliter of the cell suspension and $7 \mathrm{~m} l$ of the cell-free suspension were pipetted into a $100 \mathrm{ml}$ polyethylene bottle, with a plastic tube, then $2 \mathrm{~m} l$ of the substrate was added to make $10 \mathrm{ml}$. The bottles were shaken for $30 \mathrm{~min}$ at $37^{\circ} \mathrm{C}$, and incubations were terminated by cooling on ice. The incubation solution was used for lipid analysis.

To determine the effect of adding cobalt ions, $10 \mu \mathrm{l}$ of $1 \mathrm{M}$ cobalt chloride in Hanks solution was added to a bottel containing $8 \mathrm{ml}$ of the cell suspension and $2 \mathrm{~m} l$ of the substrate, then the bottle was capped. After incubation for $30 \mathrm{~min}$ at $37^{\circ} \mathrm{C}$, two $\mathrm{ml}$ of the cell solution was sedimented by centrifigation $(1,500 \times \mathrm{g}$ for $5 \mathrm{~min})$, and then analyzed. 


\section{LIPID ANALYSIS}

Two milliliters of the cold cell suspension was pipetted into a $40 \mathrm{~m} l$ volume tube containing $20 \mathrm{~m} l$ chloroform-methanol (2:1). The tube was capped and shaken for $5 \mathrm{~min}$, then $5 \mathrm{ml}$ of $0.5 \%$ saline solution was added and the tube was shaken again for $5 \mathrm{~min}$, after which it was allowed to stand overnight at $5^{\circ} \mathrm{C}$. The next day the tube was centrifuged for $5 \mathrm{~min}$ at $1,500 \times \mathrm{g}$ and the supernate was siphoned off. The precipitate was combined with $5 \mathrm{ml}$ of chloroform-methanol- $0.5 \%$ saline $(3: 47: 50)$. The tube was again shaken for $5 \mathrm{~min}$, then centrifuged at $1,500 \times \mathrm{g}$ for $5 \mathrm{~min}$. The upper phase was aspirated, and the $10 \mathrm{~m} l$ of the lower chloroform phase was evaporated to dryness under nitrogen at $40-50^{\circ} \mathrm{C}$. The dried lower phase was dissolved with $0.5 \mathrm{~m} l$ chloroform, then $25 \mu l$ of this solution was applied to thin-layer chromatography plates, spread with Silica Gel G (Merck, Art 5721). Hexane-ether-glacial acetic acid $(90: 10: 1)$ was used to separate lipids. Lipids were located on the plate with iodine vapor. Since triglycerides and diglycerides overlapped when developed on the thin-layer silicic acid plates, they were scraped together from plates and designated as triglycerides. The amount of cholesterol esters was too low to be detectable on the thin-layer plates. Radioactivity was measured after scraping and collecting the required segments of silica gel into counting vials. The vial was counted in a Packard TRI-CABB Scintillation spectrometer, model 2650 after $10 \mathrm{ml}$ of scintillation mixture containing PPO: POPOP: toluene $(4 \mathrm{~g}: 0.1 \mathrm{~g}$ in $1 \mathrm{~L}$ toluene) had been added.

\section{$\mathrm{CO}_{2}$ AND ACETOACETATE CAPTURE}

${ }^{14} \mathrm{CO}_{2}$ production from $\left[1{ }^{14} \mathrm{C}\right]$ palmitic acid was determined in a polyethylene vial in which a plastic tube containing $0.5 \mathrm{ml}$ of hyamine was set. At the end of $30 \mathrm{~min}$ of incubation, $0.5 \mathrm{ml}$ of $62.5 \%$ citric acid solution was allowed to be absorbed in the hyamine solution for an additional $10 \mathrm{~min}$. Methylalcohol $0.5 \mathrm{ml}$ was added to capture the ${ }^{14} \mathrm{CO}_{2}$ in hyamine, which was then transferred to a vial. In another polyethylene bottle, in which ${ }^{14} \mathrm{CO}_{2}$ had been produced for $30 \mathrm{~min}$ and absorbed in hyamine solution for another $10 \mathrm{~min}$, $2.0 \mathrm{ml}$ of aniline citrate, composed of $3.75 \mathrm{~g}$ of aniline- $\mathrm{HCl}$ plus $6 \mathrm{ml}$ of $62.5 \%$ citric acid was injected through the cap. This solution was incubated for an additional $120 \mathrm{~min}$ to decarboxylate the acetoacetic acid. Samples in the vials were counted after the addition of scintillation medium as described above. The ${ }^{14} \mathrm{CO}_{2}$ produced from ketone bodies is the value less the ${ }^{14} \mathrm{CO}_{2}$ absorbed in the hyamine solution before the addition of aniline citrate subtracted from the total ${ }^{14} \mathrm{CO}_{2}$ absorbed at the end of the additional $120 \mathrm{~min}$ incubation. The acetoacetate carboxyl radioactivity multiplied by 2 is the total acetoacetate radioactivity. Since acetoacetate and $\beta$-hydroxy butyrate are in isotopic equilibrium, the $\beta$-hydroxybutyrate radioactivity was calculated from quantities of acetoacetate and $\beta$-hydroxybutyrate found by spectrophotometric analysis according to the method of Mellanby and Williamson ${ }^{14,15)}$.

\section{ACETOACETATE ANALYSIS}

Ten milliliters of the incubation mixture containing isolated liver cells was centrifuged at $1,500 \times \mathrm{g}$ for $5 \mathrm{~min}$ at $0^{\circ} \mathrm{C}$. Seven milliliters of the supernatant was combined with $7 \mathrm{ml}$ of ice-cold $30 \%$ perchloric acid. After centrifugation at $1,500 \times \mathrm{g}$ for $20 \mathrm{~min}$ at $0^{\circ} \mathrm{C}, 10 \mathrm{ml}$ of the supernatant was adjusted to $\mathrm{pH} 7.0$ by adding $20 \% \mathrm{KOH}$ solution drop by drop with continual stirring. The white suspension in the solution was centrifuged down during this procedure. The supernatants were analyzed for acetoacetate as described above ${ }^{14}$.

\section{RESULTS}

Total conversions of palmitate to fatty acid esters, $\mathrm{CO}_{2}$ and ketone bodies in isolated liver cells from normally fed, starved and starved plus cobalt-treated animals are shown in 
Table 1. Liver cells from fed rats converted more palmitate than did those from starved rats, whereas there was no significant difference between the total conversion rates for fed and starved rabbits. The total conversion rate of palmitate for cobalt-treated rabbits was higher than that for starved rabbits, but the rate for cobalt-treated rats did not differ from that for starved rats.

As seen from Table 2, more than $90 \%$ palmitate was esterified in rabbit liver cells, whereas in cells from both starved and cobalt-treated rats a smaller per cent was esterified, and a considerable per cent was oxidized to ketone bodies. In the liver cells from cobalttreated rabbits, more than $90 \%$ of the free fatty acids esterified to triglyceride, whereas about $10 \%$ of them were esterified to phospholipids. A different pattern of esterification to triglyceride was found for cobalt-treated rats, in which about equal portions of esterified fatty acid was converted to triglycerides and phospholipids (Table 2). Phospholipid formation was similar in the liver cells of the three groups of rabbits, but the liver cells from cobalt-treated rats esterified more palmitate to phospholipids than did those of starved rats, in which phospholipid formation was less than one half that of the fed rats (Table 1). The oxidation of palmitate to $\mathrm{CO}_{2}$ was similar among the liver cells of the three groups of

\section{Table 1 Conversion of palmitate to fatty acid esters, $\mathrm{CO}_{2}$ and ketone bodies in liver cells} isolated from normally fed, starved and starved plus cobalt-treated animals

Isolated liver cells $(1.0 \mathrm{~m} l)$ were incubated for $30 \mathrm{~min}$ at $37^{\circ} \mathrm{C}$ with $10 \mathrm{ml}$ of $0.5 \%$ fatty acid free albumin-7.5 $\mu \mathrm{M}$ palmitate (containing $9.4 \mathrm{nM}\left[11^{14} \mathrm{C}\right]$ palmitate) in suspension medium. At the end of the incubation period more than $90 \%$ of the added $\left[1-{ }^{14} \mathrm{C}\right]$ palmitate was unused and was recoverd in the experiment. More than $95 \%$ of the total added palmitate radioactivity was recovered in $\mathrm{CO}_{2}$, ketone bodies, fatty acid esters, plus unused palmitate at the end of the incubation period.

\begin{tabular}{|c|c|c|c|}
\hline$i$ & FedA & Starved ${ }^{B}$ & Starved $+\mathrm{Co}^{\mathrm{C}}$ \\
\hline Rabbit & \multicolumn{3}{|c|}{$\mathrm{n}$ moles $/ \mathrm{mg}$ dry $\mathrm{wt} / 30 \mathrm{~min}$. } \\
\hline $\begin{array}{l}\text { Total conversion of palmitate to fatty } \\
\text { acid esters, } \mathrm{CO}_{2} \text { and ketone bodies }\end{array}$ & $3,354 \pm 469$ & $2,606 \pm 210$ & $3,724 \pm 241 * *$ \\
\hline Esterified fatty acids & $3,250 \pm 472$ & $2,484 \pm 198$ & $3,564 \pm 245^{* *}$ \\
\hline Triglyceride & $2,724 \pm 436$ & $1,932 \pm 149$ & $3,216 \pm 259 * *$ \\
\hline Phospholipid & $526 \pm 98$ & $552 \pm 176$ & $348 \pm 64$ \\
\hline Oxidation & $104 \pm 18$ & $122 \pm 21$ & $160 \pm 13^{\uparrow}$ \\
\hline Total ketone bodies & $74 \pm 10$ & $97 \pm 16$ & $128 \pm 13^{\dagger}$ \\
\hline Carbon dioxide & $31 \pm 9$ & $25 \pm 6$ & $31 \pm 6$ \\
\hline \multicolumn{4}{|l|}{ Rat } \\
\hline $\begin{array}{l}\text { Total conversion of palmitate to fatty } \\
\text { acid esters, } \mathrm{CO}_{2} \text { and ketone bodies }\end{array}$ & $4,444 \pm 559$ & $1,512 \pm 102^{\dagger \dagger}$ & $1,606 \pm 116^{\dagger \dagger}$ \\
\hline Esterified fatty acids & $4,166 \pm 539$ & $1,136 \pm 77^{\dagger \dagger}$ & $1,322 \pm 107^{\dagger \dagger}$ \\
\hline Triglyceride & $3,256 \pm 449$ & $712 \pm 90^{\dagger \dagger}$ & $710 \pm 79^{\dagger \dagger}$ \\
\hline Phospholipid & $910 \pm 168$ & $424 \pm 47^{\dagger}$ & $612 \pm 64^{*}$ \\
\hline Oxidation & $277 \pm 25$ & $364 \pm 25^{\dagger}$ & $284 \pm 25^{*}$ \\
\hline Total ketone bodies & $245 \pm 20$ & $318 \pm 24^{\dagger}$ & $227 \pm 21 *$ \\
\hline Carbon dioxide & $32 \pm 5$ & $46 \pm 3$ & $57 \pm 5^{\dagger}$ \\
\hline
\end{tabular}

A. Mean \pm S.E. in liver cells isolated from 5 different normally fed animals

B. Mean \pm S.E. in liver cells isolated from 5 different starved animals

C. Mean \pm S.E. in liver cells isolated from 5 different starved plus cobalt-treated animals

$*, * *$ : significant difference for starved animals, ${ }^{*} \mathrm{p}<0.05, * * \mathrm{p}<0.01$, respectively

${ }^{\dagger},{ }^{\dagger+}$ : significant difference for normally fed animals, ${ }^{\dagger} \mathrm{p}<0.05,{ }^{\dagger \dagger} \mathrm{p}<0.01$, respectively 
Table 2 Partition of free palmitate between pathways of esterification and oxidation in isolated liver cells from normally fed and starved plus cobalt-treated animals

One milliliter of isolated liver cells was incubated with $10 \mathrm{~m} l$ of $0.5 \%$ fatty acid free albumin-7.5 $\mu \mathrm{M}$ palmitate (containing $9.4 \mathrm{nM}\left[1-{ }^{14} \mathrm{C}\right]$ palmitate) for $30 \mathrm{~min}$ as described in Table 1

\begin{tabular}{|c|c|c|c|}
\hline & Fed $^{A}$ & Starved ${ }^{\mathrm{B}}$ & Starved $+\mathrm{Co}^{\mathrm{C}}$ \\
\hline Rabbit & \multicolumn{3}{|c|}{$\mathrm{n}$ moles $/ \mathrm{mg}$ dry $\mathrm{wt} / 30 \mathrm{~min}}$. \\
\hline $\begin{array}{l}\text { Total convesion of palmitate to fatty } \\
\text { acid esters, } \mathrm{CO}_{2} \text { and ketone bodies } \\
\% \text { of total conversion }\end{array}$ & $3,354 \pm 469$ & $2,606 \pm 210$ & $3,724 \pm 241 * *$ \\
\hline Fatty acid esters & 94.5 & 92.3 & 92.4 \\
\hline Triglyceride & 78.8 & 69.4 & 83.2 \\
\hline Phospholipid & 15.6 & 22.9 & 9.2 \\
\hline Oxidation & 5.5 & 7.7 & 7.6 \\
\hline Total ketone bodies & 4.5 & 6.7 & 6.8 \\
\hline Carbon dioxide & 1.0 & 1.1 & 0.8 \\
\hline Rat & \multicolumn{3}{|c|}{$\mathrm{n}$ moles $/ \mathrm{mg}$ dry $\mathrm{wt} / 30 \mathrm{~min}}$. \\
\hline $\begin{array}{l}\text { Total conversion of palmitate to fatty } \\
\text { acid esters, } \mathrm{CO}_{2} \text { and ketone bodies } \\
\% \text { of total conversion }\end{array}$ & $4,444 \pm 559$ & $1,512 \pm 102^{t t}$ & $1,606 \pm 116^{\dagger \dagger}$ \\
\hline Fatty acid esters & 88.4 & $62.6^{\dagger \dagger}$ & $72.1^{* * t t}$ \\
\hline Triglyceride & 69.2 & $38.9^{t t}$ & $38.7^{\dagger t}$ \\
\hline Phospholipid & 19.2 & 23.6 & $33.4^{\dagger \dagger}$ \\
\hline Oxidation & 11.6 & $37.4^{t \dagger}$ & $28.0 * * t t$ \\
\hline Total ketone bodies & 10.9 & $34.9^{t t}$ & $24.9 * *+\dagger$ \\
\hline Carbon dioxide & 0.7 & 2.5 & $3.1^{\dagger}$ \\
\hline
\end{tabular}

A. Mean \pm S.E. in liver cells isolated from 5 different normally fed animals

B. Mean \pm S.E. in liver cells isolated from 5 different starved animals

C. Mean \pm S.E. in liver cells isolated from 5 different starved plus cobalt-treated animals

$*, * *$ : significant difference for starved animals, $* \mathrm{p}<0.05, * * \mathrm{p}<0.01$, respectively

${ }^{\dagger},{ }^{t \dagger}$ : significant difference for normally fed animals, ${ }^{\dagger} \mathrm{p}<0.05,{ }^{\dagger \dagger} \mathrm{p}<0.01$, respectively

rabbits, but in cells from cobalt-treated rats $\mathrm{CO}_{2}$ formation was higher than that in cells from fed rats (Table 1 ).

Ketogenesis in the liver cells from starved rabbits was either similar to that of the fed control, or to that of the cobalt-treated rabbits. In the liver cells from rats, the total ketone bodies formation was enhanced by starvation, and cobalt acted to reduce elevated ketogenesis to the level found in fed rats. Table 3 shows that the whole blood ketone bodies concentration in the starved rabbits increased more than four fold that of the fed ones, whereas in cobalt-treated rabbits the concentration was lower than that of the starved ones, but higher than that of the fed rabbits. The changes in blood ketone bodies in the rabbits are in good agreement with the ketogenesis observed in isolated rat liver cells, but they do not correspond to values for rabbit liver cells.

To determine the effect of cobalt ion on fatty acid metabolism in the isolated liver cells, cobalt chloride was added to the medium and incubated for $30 \mathrm{~min}$. Fig. 1 shows that neither esterification nor oxidation to ketone bodies formation was affected whether the medium contained cobalt chloride or not.

The secretion of triglyceride from the liver was compared for each of the isolated liver cells from the three groups of rabbits. Mean secretion rates from 5 studies are shown in 
Table 3 Effect of starvation and of cobalt-treatment on total ketone bodies concentration in the whole blood of rabbits

\begin{tabular}{c|c|c|c}
\hline & Normally fed & Starved & Starved + Co \\
\hline $\begin{array}{c}\text { Blood ketone bodies } \\
\text { n moles } / \mathrm{m} l\end{array}$ & $188.4 \pm 11.0$ & $752.7 \pm 51.4^{\dagger \dagger \dagger}$ & $562.0 \pm 22.0 * \ldots * *$ \\
$(6)$ & $(6)$ & $(6)$
\end{tabular}

Number of rabbits in each group is in parentheses

$*$ : significant difference for starved, *** $\mathrm{p}<0.001$

${ }^{\dagger}$ : significant difference for normally fed, ${ }^{+\dagger \dagger} \mathrm{p}<0.001$

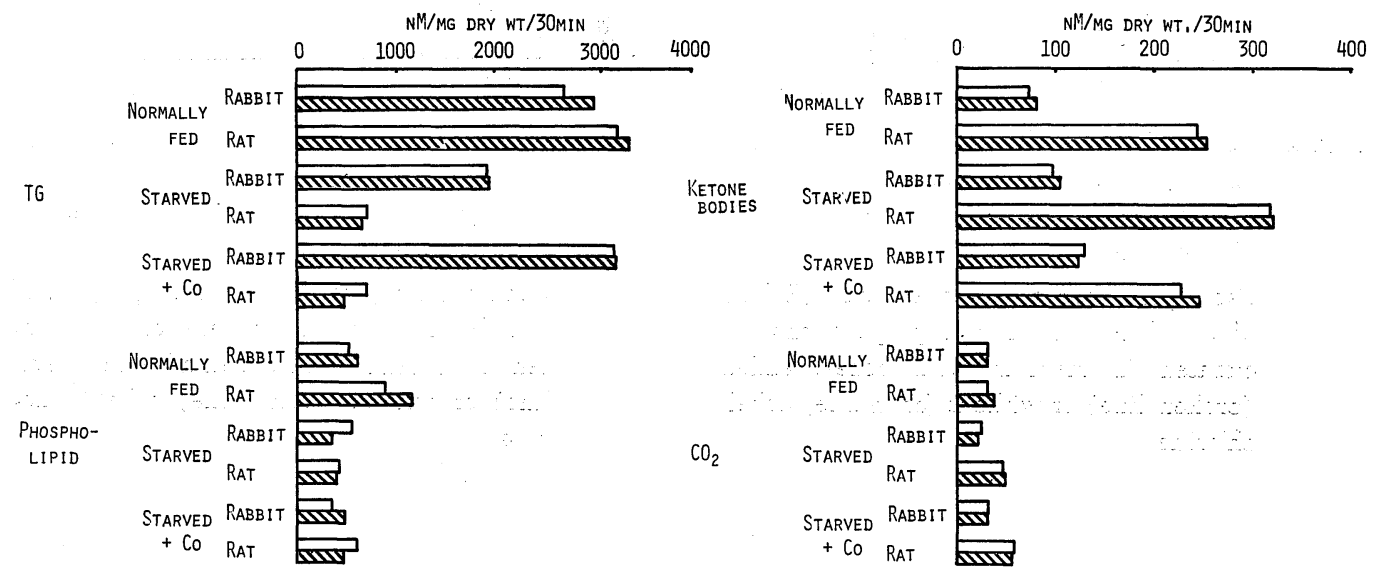

Fig. 1 Effect of an addition of cobalt chloride on the conversion of palmitate to triglyceride (TG), phospholipids, $\mathrm{CO}_{2}$ and ketone bodies in liver cells isolated from normally fed, starved and starved plus cobalt-treated animals

Each bar represents the mean of 5 different liver cell preparations. Conversion of palmitate is represented by the total length of a bar. The white bar is the conversion rate without the addition and the shaded bar is that with the addition of Co to the incubation medium.

Fig. 2. Triglyceride secretion increased linearly from 0 to $3 \mathrm{hr}$. Liver cells from normally fed rabbits secreted about four times the amount of triglyceride fatty acid that the starved ones secreted at $3 \mathrm{hr}$, and cells from cobalt-treated rabbits secreted about twice as much as did cells from starved rabbits. Because of the great variation in triglyceride amounts from animal to animal the difference between the cobalt-treated and starved animals did not have statistical significance.

An addition of $1 \mathrm{M}$ cobalt chloride to the medium markedly suppressed triglyceride release from the cells in all three groups (Fig. 2). The effect of cobalt chloride on the secretion of acetoacetate was examined in isolated liver cells from the three groups of rabbits. A parallel increase in acetoacetate secretion was seen in all three groups. This indicates that the addition of cobalt did not affect the secretion of acetoacetate from the liver cells (Fig. 3). 


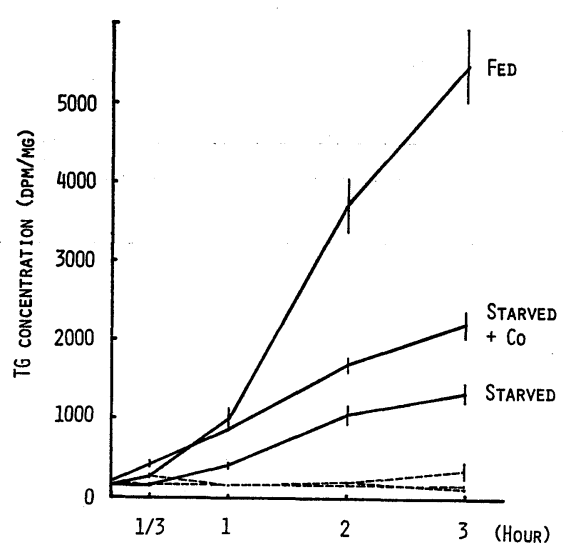

Fig. 2 Effect of cobalt chloride on the secretion of triglyceride from isolated liver cells of normally fed, starved and starved plus cobalt-treated rabbits

Each point represents the mean \pm S.E.M. of 5 different liver cell preparations incubated in medium with cobalt added (broken line) or without (solid line) cobalt chloride

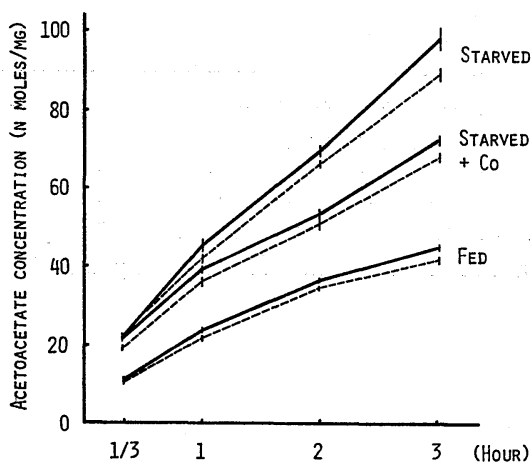

Fig. 3 Effect of cobalt chloride on the secretion of acetoacetate from isolated liver cells of normally fed, starved, and starved plus cobalt-treated rabbits

Each point represents the mean \pm S.E.M. of 5 different liver cell preparations incubated in medium with cobalt added (broken line) or without (solid line) cobalt chloride

\section{Discussion}

The fate of labelled free fatty acids in isolated perfused livers showed that on entering the liver they were esterified or oxidized ${ }^{16}$. For any given infusion of labelled free fatty acids, the fed livers always esterified more of the influx than did the starved livers, and the latter always oxidized more than the former $\operatorname{did}^{17}$. In an experiment using liver homogenates, Varrečka et al.18) reported that liver cells from rats incorporated less palmitate into glycerides and phospholipids than did those of fed animals. On comparing the synthesis of lipids in isolated intact liver cells prepared by mechanical and enzymatic methods, Jezek and Liberti ${ }^{19}$ ) reported that cells prepared enzymatically were superior to those prepared mechanically in all respects. Sundler et al. ${ }^{12)}$ and Ontko11) confirmed that enzymatically isolated rat hepatocytes retained several of the characteristic features of glycerolipid biosynthesis. Our present data also indicate that isolated hepatocytes are of value for studies on the regulation of hepatic lipid metabolism.

The total rate of utilization of added free fatty acid was decreased by starvation in both the rabbit and the rat. Ontko reported that the total conversion of palmitate to fatty acid esters, $\mathrm{CO}_{2}$ and ketone bodies in isolated liver cells from the rat was unaffected by starvation. This discrepancy between our study and Ontko's in the total rate of utilization of added free fatty acid may be explained by the differences in starvation periods; starvation for three days in our study and for $24 \mathrm{hr}$ in his.

The present study shows that liver cells from starved rats exhibited a marked reduction in esterification and a significant increase in ketogenesis; whereas in cells from starved rabbits, neither the decrease in esterification nor the increase of oxidation was significant. The difference in the lipid metabolism of these rats and rabbits may be due to the degree of starvation; the starved state of the herbivorous rabbit may have less affect on its lipid metabolism than would the starved state of the omnivorous rat. 
Groener and Van Golde ${ }^{20)}$ observed that fasting of the rat strongly decreased triglyceride synthesis in isolated hepatocytes, whereas the synthesis of phospholipids was much less affected by fasting. The data presented in Tables 1 and 2 support the data of Groener and Van Golde in the case of the rat, and indicates that starvation lowers esterification, and causes decreased formation of hepatic triglycerides and phospholipids. In isolated liver cells from the rabbit, however, starvation could not decrease triglyceride synthesis and scarcely affected phospholipid formation. There is very little information on why the starvation affect varies from species to species. As stated previously the discrepancy may be due to the degree of starvation in animals and to whether they are herbivores or omnibores.

Liver cells from starved rats oxidized added more palmitate to ketone bodies and $\mathrm{CO}_{2}$ than did cells from fed rats; this coincides with previous observations. Liver cells from starved and fed rabbits similarly oxidized palmitate to ketone bodies and $\mathrm{CO}_{2}$. This indicates that the starvation affect on the oxidation of fatty acids operates in a different way from species to species.

The isolated liver cells from cobalt-treated rabbits esterified more added palmitate to form triglyceride than did cells from starved rabbits. In liver cells from cobalt-treated rats, triglyceride formation remained at the same low level as that of starved rats, whereas phospholipid formation was greater in cells from cobalt-treated rats than in those from starved rats. Thus even if starvation acts to lower esterification, the cells from cobalt-treated rabbits esterify more incoming palmitate to triglyceride, but those from cobalt-treated rats esterify more to phospholipid. The preponderance of triglyceride formation in cells from cobalt-treated rabbits may explain why the hypertriglyceridemia induced by cobalt chloride injected into rabbits was far more marked than that for a similarly treated rat. The similar amount of $\mathrm{CO}_{2}$ production observed for both rabbits and rats, whether the animals were starved or cobalt-treated, suggests that the citric acid cycle activity was not depressed in the hepatocytes of cobalt-treated animals. This is not in agreement with results reported for the depressed cellular respiration of liver in cobalt-treated rats. These experiments provide further evidence that decreased ketogenesis in cobalt-treated rats is not the result of accelerated citric acid cycle activity, and that decreased ketogenesis can occur without this acceleration.

Cobalt chloride added to the medium affected neither esterification nor oxidation of the palmitate in isolated liver cells from rabbits and rats (Fig. 1). The secretion of labelled triglyceride from rabbit liver cells was depressed when cobalt chloride was added to the incubation medium (Fig. 2). The secretion of acetoacetate from isolated rabbit liver cells was not altered whether cobalt chloride was added to the incubation medium or not (Fig. 3). These results suggest that cobalt could not affect the lipid metabolism of the cells during a short incubation period of $20 \mathrm{~min}$, or that a considerable amount of cobalt remained on the surface of cell membrane and prevented the lipoprotein molecule, in which triglyceride is involved, from being released, but smaller molecules such as acetoacetate could pass through the membrane. Daniel et al. ${ }^{7)}$ and $\mathrm{Webb}^{8)}$ demonstrated that in a short incubation period the cobalt ion could not inhibit oxygen uptake in rat liver slices and suggested that $7 \mathrm{hr}$ of incubation is necessary before significant inhibition occurs. De Moraes and Mariano ${ }^{21}$ also confirmed that in isolated tissues cobalt did not provoke a significant reduction in oxygen uptake, whereas in rats previously injected with cobalt sulphate, inhibition of oxygen uptake occurred in the liver slices after $24 \mathrm{hr}$.

Henquin and Lambert ${ }^{22}$ demonstrated that $\mathrm{Co}^{++}$inhibited immunoreactive insulin secretion through an antagonistic action on $\mathrm{Ca}^{++}$entry in isolated rat beta cells. They showed that glucose-induced IRI release was inhibited by $\mathrm{Co}^{++}$. In the present experiment, liver cells, not beta cells, were incubated in the medium without $\mathrm{Ca}^{++}$and glucose, and 
secretion of triglyceride from these isolated liver cells was inhibited. $\mathrm{Co}^{++}$entry into the liver cells is a possible cause of the inhibition of triglyceride release from hepatocytes.

Sundler et al. ${ }^{12}$ ) reported that cycloheximide and colchicine strongly inhibited the secretion of labelled triacylglycerols from enzymatically isolated rat liver parenchymal cells. Cycloheximide and colchicine did not depress the incorporation of labelled glycerol into cellular lipids, but the proportion released into the medium was drastically lowered. Neither did cobalt added to the incubation medium affect triglyceride synthesis but it did inhibit secretion. The mechanisms involved in these differences needs more extensive study.

\section{SUMMARY}

Effects of starvation and cobalt injection on lipid metabolism were studied in isolated liver cells from three groups of animals; normally fed, starved and starved plus cobalt-treated rats and rabbits.

The nutritional state of the rat has a profound influence on the total conversion of palmitate to fatty acid esters and ketone bodies. Starvation of rats markedly decreased the esterification of palmitate into triglycerides and significantly increased oxidation into ketone bodies. Starvation of rabbits, scarcely affected the esterification and oxidation of added palmitate.

Enhanced esterification of labelled palmitate into triglyceride was shown by isolated liver cells from cobalt-treated rabbits, whereas liver cells from cobalt-treated rats were characterized by increased conversion of added palmitate to phospholipids and by decreased ketogenesis. A marked elevation in blood ketone bodies concentration in starved rabbits and its suppresion by cobalt treatment coincides with the alteration of ketone body formation in liver cells from rats, in which ketogenesis was increased by starvation and suppressed by cobalt treatment.

Cobalt added to the incubation medium did not affect the esterification and oxidation of palmitate in the isolated liver cells from three groups of animals.

Secretion of triglyceride from the isolated liver cells was completely suppressed when cobalt was added to the incubation medium, whereas secretion of acetoacetate from the cells was unaffected by the added cobalt.

These results indicate that cobalt added to the incubation medium affects neither the lipid metabolism in isolated liver cells nor the secretion of acetoacetate from the cells, but that it completely inhibits the secretion of triglyceride.

Acknowledgements: We express our thanks to Professor Shigeo Koike for his many helpful suggestions and constant guidance during this study. We also wish to thank Dr. Masayoshi Ohmichi and Miss Nobuko Nemoto for their generous assistance in carrying out the experiments.

\section{REFERENCES}

1) Asano, S.: Hypertriglyceridemia induced by the injection of cobalt chloride into rabbits, Showa Med. J., 36, 411-417 (1976).

2) Ohmichi, M., Morita, H., Onuma, Y. and Koike, S.: Effect of cobalt chloride on the blood glucose, plasma insulin and lipids in rabbits, Jap. J. Hyg., 27, 532-536 (1974).

3) Ohmichi, M., Morita, H., Inami, I. and Koike, S.: The effect of cobalt chloride on the lipid metabolism in rabbit liver: changes in plasma insulin, hepatic lysosomal triglyceride lipase, $\alpha$-glycerophosphate and cyclic AMP concentrations, Jap. J. Hyg., 30, 579-585 (1975).

4) Kuno, Y., Nemoto, N., Morita, H. and Koike, S.: Elevation of plasma sialic acid and serum hapto. globin in experimental animals in relation to triglyceridemia induced by cobalt chloride administration, Jap. J. Hyg., 34, 484-487 (1979). 
5) Eaton, R. P.: Cobalt chloride-induced hyperlipemia in the rat: effects on intermediary metabolism, Am. J. Physiol., 222, 1550-1557 (1972).

6) Havel, R. J., Felts, J. M and Van Duyne, C. M.: Formation and fate of endogenous triglycerides in blood plasma of rabbits, J. Lip. Res., 3, 297-308 (1962).

7) Dingle, J. T., Heath, J. C., Webb, M. and Daniel, M.: The biological action of cobalt and other metals. II. The mechanism of the respiratory inhibition produced by cobalt in mammalian tissues, Biochim. Biophys. Acta. 65, 34-36 (1962).

8) Webb, M.: The biological action of cobalt and other metals. III. Chelation of cations by dihydrolipoic acid, Biochim. Biophys. Acta, 65, 47-65 (1962).

9) Ohyama, K., Morita, H., Hasegawa, T. and Koike, S.: Effect of cobalt chloride on the content of lipid and glycolytic intermediates in rabbit liver and heart, Jap. J. Hyg., 28, 456-462 (1973).

10) Morita, H., Ohmichi, M., Inami, I. and Koike, S.: Plasma triglyceride turnover in cobalt-treated rabbits, Jap. J. Hyg., 29, 525-531 (1974).

11) Ontko, J. A.: Metabolism of free fatty acids in isolated liver cells: Factors affecting the partition between esterification and oxidation, J. Biol. Chem., 247, 1788-1800 (1972).

12) Sundler, R., Åkesson, B. and Nielson, Å.: Triacylglycerol secretion in very low density lipoproteins by isolated rat liver parenchymal cells, Biochem. Biophys. Res. Commun., 55, 961-968 (1973).

13) Berry, M. N. and Friend, D. S.: High-yield preparation of isolated rat liver parenchymal cells, J. Cell. Biol., 43, 506-520 (1969).

14) Williamson, D. H. and Mellanby, J.: D-(-)-3-Hydroxybutyrat in Methoden der enzymatischen Analyse herausgegeben von H. U. Bergmeyer, p. 1772. Verlag Chemie Weinheim/Bergstr. (1970).

15) Mellanby, J. and Williamson. D. H.: Acetoacetat in Methoden der enzymatischen Analyse herausgegeben von H. U. Bergmeyer, p. 1776. Verlag Chemie Weinheim/Bergstr. (1970).

16) Mayes, P. A. and Felts, J. M.: Regulation of fat metabolism in the liver, Nature, 215, 716-718 (1967).

17) Mayes, P. A.: Studies on the major pathways of hepatic lipid metabolism using the perfused liver, in "Adipose tissue, regulation and metabolic functions", Academic Press, New York, edited by Levine, R. and Pfeiffer, E. F., 186-195 (1970).

18) Vavrecka, M., Mitchell, M. P. and Hübscher, G.: The effect of starvation on the incorporation of palmitate into glycerides and phospholipids of rat liver homogenates, Biochem. J., 115, 139-145 (1969).

19) Jezyk, P. F. and Liberti, J. P.: Metabolic activities of mechanically and enzymatically prepared rat liver cells, Arch. Biochem. Biophys., 134, 442-449 (1969).

20) Groener, J. E. M. and Van Golde, L. M. G.: Effect of fasting and feeding a high-sucrose, fat-free diet on the synthesis of hepatic glycerolipids in vivo and in isolated hepatocytes, Biochim. Biophys. Acta, 487, 105-114 (1977).

21) De Moraes, S. and Mariano, M.: Biochemical aspects of cobalt intoxication. Cobalt ion action on oxygen uptake, Med. Pharmacol. Exp., 16, 441-447 (1967).

22) Henquin, J. C. and Lambert, A. E.: Cobalt inhibition of insulin secretion and calcium uptake by isolated rat islets, Am. J. Physiol., 228, 1669-1677 (1975).

\title{
コバルトによる家鬼およびラットの肝遊離細胞における 脂肪酸の代謝に及ぼす影響について
}

\author{
森 田博行·久野由基一 \\ 昭和大学医学部 衛生学教室
}

\footnotetext{
正常食, 3 日間空腹, 3 日間空腹十塩化コバルト注射の 3 群の家鬼とラットの肝遊離細胞について, 空腹状態, あるいはコバルト注射が遊離脂肪酸の代謝にどのように影響するかを観察した。

空腹ラットの肝細胞では, 標識パルミチン酸のエステル化は正常食ラットに比べて著しく減少したが, ケトン
} 
体への酸化の転換総量は増加した。このエステル化の減少はトリグリセライド (TG) と燐脂質の生成の減少によ るが，とりわけ TG の生成の減少が大きく影響していた。しかしケトン体の生成は空腹によって交進した。他方, 家鬼の肝細胞では脂肪酸のエステル化と酸化は空腹によって殆んど影響されなかった。

コバルト注射家鬼の肝細胞では標識したパルミチン酸の TGへのエステル化が空腹家鬼に比へてて進した。し かし，コバルト注射ラットの肝細胞では TGへのエステル化は空腹ラットと差がなかったが, 燐脂質の生成は, 促進し，ケトン体生成は有意に減少した。

空腹の家鬼では血中のケトン体は顕著に増加したが, コバルト注射によってその増加は抑制された。乙の家鬼 の血中のケトン体の変動は, 空腹ラットの肝細胞におけるケトン体生成の増加とコバルト注射によるその増加の 抑制というラットの肝細胞の挙動にむしろ近かった。

3 群の動物の遊離肝細胞を浮遊した培養液にコバルトを加えたととろ標識したパルミチン酸のエステル化と酸 化の度合には，添加しないあのに比べて，なんらの差がみられなかった。

培養液にコバルトを添加すると 3 群の遊離肝細胞からの TG の放出が抑制されたが，アセ卜酶酸の放出は阻害 されなかった。即ち, 培養液にコバルトを添加しても遊離肝細胞の TG の生成とアセ卜酢酸の放出には影響しな かったが TG の放出は完全に阻害された。

（受付 1978年11月24日） 